\title{
OBITUARIES
}

1316

\author{
Mr. P. Bruce White, F.R.S.
}

THE scientific achievemefor of Philip Bruce White, who died on March 19 arf the age of fifty-seven, was a remarkable exan of of a contribution to medical bacteriology by a non-medical man. Bruce White came of a segush family whose connexions included the late 1 . J. C. Philip and Sir Robert Philip, the we-known professor of tuberculosis in Edinburgh. He hindself was born and brought up in Bangor, where his father, P. J. White, was the first lecturer in zoology and later for many years professor of this subject in the University College of North Wales. It was from his father that Bruce White aequired his enduring interest in biology, although the intellectual approaches of the two men to the subject had little in common; the father was a natural historian with the interests and the habits of mind of the collector, whereas the son was above all a versatile and ingenious experimenter.

Bruce White was educated at Friar's School, Bangor, and later at the University College of North Wales, where he graduated in science in 1915, his chief subjects being botany and zoology; his first essay in bacteriology was an undergraduate research on black rot in mangolds. His original intention had been to study medicine after graduation in science, but the desire to take a more active part in the First World War caused him to abandon this plan, although he did go so far as to take an extramural course in human anatomy at Edinburgh. With the object of improving his knowledge of bacteriology he went to the Lister Institute, where he came under the influence of the late Sir Joseph Arkwright. After a few months he accepted a post as assistant pathologist at Trinity College, Dublin, an appointment which plunged him into work far outside his experience and eventually involved him in the excitement of the Easter Kebellion of 1916.

Bruce White finally found direct war-time employment when he was appointed civilian pathologist at Tidworth Military Hospital, where he worked until 1919. On his release from this duty he joined a team working on bee disease at Aberdeen, and here he found the opportunity for his first important scientific contribution. It was due to his shrewd observation that a mite infestation was identified as the cause of Isle of Wight disease in bees.

Having left Aberdeen, and after an interval of teaching at Bangor and work for the Fisheries Board, Bruce White in 1921 joined in studies of food poisoning organised by the Medical Research Council and the Ministry of Health ; this appointment marked the beginning of his serious career as a bacteriologist and of the work for which he will be chiefly remembered, namely, his studies of the Salmonella group. The research extended over many years; it was conducted first under Dr. W. G. Savage at Bristol and later at the Lister Institute and at the National Institute for Medical Research, which he joined as a member of the scientific staff of the Medical Research Council in 1927; it led to the classification of a most important group of organisms and provided the basis for diagnostic methods now universally employed. In more recent years Bruce White worked principally on cholera; here again his interest was mainly in the precise characterization of the pathogenic strains of cholera vibrios and in their relationships to harmless related organisms. The reputation which he had established as an authority on the bacteriology of cholera caused him to be invited to India in 1946 to take part in and advise on cholera research in that country, and in 1947 to be sent to investigate the epidemic of cholera in Cairo.

Bruce White was something of an original in medical research. He was essentially an individual investigator, unsystematic in his methods and having a curious nocturnal habit of work as unconventional as had been his training. His zeal for experimentation far outran his inclination to keep records. With all this he achieved much, and his main contributions will live in the history of bacteriology. Outside his work he had a keen interest in art and a deep knowledge and appreciation of French literature. He was a man with a keen sense of humour and a great kindliness of nature. Above all, he had the lovable characteristic of a catholic gift for friendship, and for this he will be held in affectionate remembrance by all who knew him. The sympathy of his many friends will be with his widow and two sons in their bereavement.

C. R. HaRrNGton

\section{Capt. G. C. Shortridge}<smiles>[C]#C</smiles>

Capt. Guy C. Shortridge, director of the Kaffrarian Museum, King William's Town, South Africa, died suddenly thifle working alone in the Museum on January 12 He was born on June 21, 1880, at Honiton $/$ Devon, where his father was in medical prafete. From his earliest youth, Shortridge was inferested in natural history, and after serving in the South African Constabulary during the Boer War, he was engaged by the late Mr. W. L. Sclater, then director of the South African Museum, to collect mammals and birds in Pondoland and the Colesberg district. After he had returned to England, he made the acquaintance of Oldfield Thomas, who arranged for him to collect mammals and birds in south-west Australia. Then he went to west Java and brought back a great collection of 1,500 mammals. In 1908 he went to Guatemala to obtain live animals for the Zoological Society, and on his return joined the British Ornithologists' Union jubilee expedition to New Guinea. In 1911 the Bombay Natural History Society inaugurated a mammal survey, and Shortridge was engaged to collect for the Society. He did good work in southern India and then was sent to Burma. Previously little systematic collecting had been done there, and our present knowledge of the mammals of that country is due to his excellent work.

He saw service in the First World War in France, Palestine and Iraq, where he was attached to the Royal Air Force as an observer. After the signing of the armistice he was appointed second-in-command of the R.A.F. Cape-to-Cairo aerodrome survey, and, on completion, went to collect mammals in Northern Rhodesia for the British Museum. While on that expedition he was appointed director of the Kaffrarian Museum, and took charge in 1921. Thereafter, searcely a year passed without Shortridge making an expedition to some part of the Union. He first confined his attention to South-west Africa, financed partly by the Percy Sladen Memorial Fund, and the results of the expedition were described by Thomas and Hinton. In 1930-33 he published "The Mammals of South-west Africa". 
At the outbreak of the Second World War he volunteered for service; but his age prohibited him from seeing active service, though he did good work in charge of a base camp in Abyssinia. Previous to that he compiled a very useful little gazetteer of Abyssinia for the use of the troops. After the defeat of the Italians, Shortridge returned to the Museum, and as soon as the War was over started making expeditions again. In 1946, accompanied by $\mathrm{Mr}$. A. S. Vernay, of New York, who financed the expedition, Shortridge extended his investigations to Nyasaland. Only last year, when sixty-eight, he made a very successful collecting trip to the Albany district.

During his twenty-eight years service in the Kaffrarian Museum, Shortridge undertook thirteen collecting expeditions in search of mammals, with the result that the Museum now contains some 25,000 specimens-a unique collection of South African mammalian fauna. Although Shortridge's chief interest was in mammals, he did not neglect other groups, and, as a result of his extensive collecting, the Museum collections have quite outgrown the original building. Recently plans were prepared for building an extension.

Shortridge was a great collector, and wherever he went he always made friends and interested people in his work. He was the leading authority on South African mammals, and though he did not write many papers, he had a very wide knowledge which was always available to his correspondents. Expeditions cannot be run without funds, and Shortridge had a wonderful way of raising money and co-operating with other museums.

\section{Prof. Douglas Hay}

In these days, when the appeal is for men of experience to run the world's industries, the sudden silencing of an authentic voice is a matter for sorrow deeper than the grief so often hidden beneath the vesture of public or official mourning. The death, on February 24 at the age of sixty, of Prof. Douglas Hay, one of the two chief mining engineers of the National Coal Board and a past-president of the Institution of Mining Engineers, has left a gap in the industry that will be hard to fill. For he had travelled the trying road of experience and passed the milestones of change in mining until he reached the highest position in his profession. Those who knew that quiet, unassuming charm which was so big a feature of his life understood fully that it was an advancement due not only to his great technical and administrative ability, but also to a sympathetic personality that enabled him to get on well with those with whom he came into contact. He won the affection of miners through sympathetic personality, an unending thought for others, and a friendship that had no bounds.

Douglas Hay went to King Edward VI Grammar School, East Redford, and later to University College, Nottingham, with mining in his blood. His father was Mr. W. Hay, a mining engineer, of Sheffield. There were no favours for young Hay. He worked underground at Tinsley Park Colliery, was later apprenticed at Shirebrook Colliery, Notts, and in 1910 he obtained his first-class colliery manager's certificate; two years later, he received the James Forrest Medal and Miller Prize of the Institution of Civil Engineers. He delivered the first Cadman
Memorial Lecture of the Royal Society of Arts in 1947, and the William Menelaus Lecture in the same year to the South Wales Institute of Engineers. $\mathrm{He}$ was honorary professor of mining in the University of Sheffield.

Prof. Hay had been H.M. Inspector of Mines in Durham and later in North Staffs. He was general manager of Newton Chambers and Co.'s collieries, Chapeltown; managing director of Barrow Barnsley Main Collieries, Ltd., and of the Barnsley District Coking Co., Ltd.; and technical director of Wombwell Main Colliery Co., Ltd. He was a member of the Holland Committee on Qualifications of Colliery Officials ; consulting engineer, in conjunction with the late Dr. J. S. Haldane, on ventilation problems of the Mersey Tunnel ; and later adviser on ventilation for the Dartford-Purfleet Tunnel under the Thames, and important war-time underground factories.

The Midland Institution of Mining Engineers elected him president in 1923, and he remained in that position until 1936. In 1928 he became a member of the Council of the Institute of Mining Engineers. Mining gave him its greatest honour when, in 1945, the Institute of Mining Engineers elected him as its president, and the work which he did in the three years of his office will always remain his memorial.

Prof. Hay's outstanding contribution, which will have far-reaching influence, perhaps for generations, was his work, often against strong opposition, in connexion with the raising of the standard and professional status of mining engineers, culminating in the associate membership examinations of the Institute of Mining Engineers announced in 1946, the introduction of groups, and the raising of the qualifications required for admission, pending the introduction in 1952 on a compulsory basis of the associate membership examinations.

\section{Mr. John Ardagh}

JoHN ARDAGH /W fontorn at Fulham on June 15, 1885, and died Maidstone on March 8 last. At an early oone was taken to Ireland by his parents, apd fen fourteen, became a boy attendant at the Dufy Museum. In 1919 he was transferred to the British(Museum (Natural History) and worked in the herbarium. After three years he was appointed clerk-in-charge of the Botanical Library. He soon proved his capabilities as a librarian and gradually built up a considerable reputation among his colleagues and with visitors. The richness of the Library in manuscripts and drawings, as well as in old books, provided him with abundant scope for the exercise of his special qualities. He was ever ready to give freely of his knowledge or to search for facts of interest to others. He contributed several bibliographical notes to the Journal of Botany, and, with H. W. Renkema, gave an account of the various editions of A. B. Lambert's "Pinus", in the Journal of the Linnean Society. He was elected an associate of the Linnean Society in 1939. In addition to his keenness on everything connected with the 'circles' of Sloane and Banks, he made a hobby of the history of old London, and often contributed to Notes and Queries.

Ardagh was of quiet and somewhat stolid demeanour, slow moving but mentally alert, and warmhearted. He retired from the Museum in September 1947 on account of ill-health, and was never well enough to visit it again. J. RAMSBOTTOM 